\title{
ANALISIS EFEKTIVITAS SISTEM INFORMASI MANAJEMEN PENERIMAAN PENGELOLAAN PERMOHONAN ADMINISTRASI KEPENDUDUKAN (SIMP3AK) PADA DINAS PENCATATAN SIPIL KOTA MAGELANG
}

\author{
Panji Afandi, Ghina Fitri Ariesta Susilo* \\ Universitas Tidar \\ *e-mail: panjiavandi25@gmail.com
}

\begin{abstract}
DiPublikasi: 01/01/2021
http://dx.doi.org/10.22225/kr.11.2.1154.190-196
\end{abstract}

\begin{abstract}
This study aims to determine the effectiveness of the Management Information System for Receiving Management of Population Administration Requests (SIMP3AK) at the Magelang City Civil Registry Office. Data collection using interview, observation and documentation techniques. The accuracy of the data from the Management Information System for Receiving Management of Population Administration Requests (SIMP3AK) considered to be more accurate when compared to the manual system, because all population data is stored in a data base, so that when the population data is needed the operator only needs to access the existing data. But there are still weaknesses of the SIMP3AK program, namely there are population data errors, photo errors with the data listed. The implementation of the Management Information System for Acceptance of Management of Population Administration Requests (SIMP3AK) at the Magelang City Civil Registry Office has been going well, although there are still some shortcomings. It is expected that services to the community especially population administration can be better and maximal.

Keywords: System Information Management Acceptance of Management of Population Administration Requests, Effectiveness, Implementation

Abstrak

Penelitian ini bertujuan untuk mengetahui efektivitas Sistem Informasi Manajemen Penerimaan Pengelolaan Permohonan Administrasi Kependudukan (SIMP3AK) Pada Dinas Pencatatan Sipil Kota Magelang. Pengumpulan data menggunakan metode wawancara, observasi dan dokumentasi. Keakuratan data dari Sistem Informasi Manajemen Penerimaan Pengelolaan Permohonan Administrasi Kependudukan (SIMP3AK) dinilai sudah lebih akurat jika dibandingkan dengan sistem manual, karena semua data penduduk disimpan dalam data base, sehingga pada saat data penduduk dibutuhkan operator tinggal mengakses data yang telah ada. Namun masih terdapat kelemahan dari program SIMP3AK yaitu terdapat kesalahan data penduduk, kesalahan foto dengan data yang tercantum. Pelaksanaan implementasi Sistem Informasi Manajemen Penerimaan Pengelolaan Permohonan Administrasi Kependudukan (SIMP3AK) pada Dinas Pencatatan Sipil Kota Magelang sudah berjalan dengan baik, walau masih terdapat beberapa kekurangan. Diharapkan pelayanan kepada masyarakat khususnya administrasi kependudukan dapat lebih baik dan maksimal.
\end{abstract}

Kata Kunci : Sistem Informasi Manajemen Penerimaan Pengelolaan Permohonan Administrasi Kependudukan, Efektivitas, Penerapan

\section{PENDAHULUAN}

Dinas Kependudukan dan Pencatatan Sipil Kota Magelang adalah lembaga yang memiliki kewajiban utama dan fungsi melangsungkan wewenangan pada bidang administrasi kependudukan di Kota Magelang. Dinas Pemerintah adalah lembaga yang berperan guna mengabdi kepada masyarakat. Administrasi kependudukan merupakan serangkaian aktivitas penyusunan dan pengolahan dari pendaftaran penduduk, pencatatan sipil, pengelolaan data kependudukan yang menghasilkan surat dan data kependudukan serta memanfaatkan data yang dihasilkan untuk kepentingan pelayanan publik pada sektor pemerintahan dan pembangunan. Pembuatan dokumen kependudukan seperti identitas, kartu maupun surat kependudukan yang mudah mengalami perubahan harus diperhatikan dengan seksama pada proses registrasi pendataan kependudukan (Slamet, D., Retnadi, E., \& Partono, 2012).

Pemerintahan harus menjalankan pelayanan publik secara efektif dan efisien beralaskan jenis 
pelayanan yang diberikan terhadap masyarakat, pelayanan harus dijalankan mulai pemerintah pusat, provinsi hingga pemerintahan daerah. Kegiatan ini sejalan dengan ketetapan Kementrian Pemanfaatan Aparatur Negara dan Reformasi Birokrasi Republik Indonesia No. 63/Kep/M.PAN/7/2003 berkaitan dengan pelaksanaan penyelenggaraan pemerintah, pelayanan publik merupakan hal utama yang harus diberikan oleh aparatur pemerintah. Instansi pemerintah menjalankan layanan publik dalam usaha memenuhi kebutuhan masyarakat, instansi pemerintah, dan badan hukum yang berfungsi untuk penyelenggara peraturan perundang-undangan. Masyarakat berhak mendapatkan pelayanan publik yang berkualitas serta kebijakan yang jelas. Permintaan masyarakat untuk mendapat pelayanan publik terus berkembang sejalan dengan kesadaran bahwa sebagai warga negara mempunyai hak untuk dilayani.

Menurut (Suwarno, 2008) pelayan inovasi dapat berbentuk barang maupun jasa yang baru, penerapan teknologi terbaru, kegiatan produksi yang baru, perencanaan sistem yang terstruktur serta administrasi maupun pembaruan program untuk pengurus organisasi. Unsur-unsur penerapan yaitu : a) Terdapat suatu kegiatan yang dilakukan, b) terdapat pihak yang menjadi sasaran, yaitu masyarakat yang menjadi sasaran atau objek yang dituju serta diharapkan mendapatkan manfaat atas kegiatan yang dilakukan, c) adanya tindakan nyata atas penyelenggaran dari penerapan kegiatan baik individu maupun kelompok yang bertanggung jawab. Ketepatan pelayanan pada setiap sistem pelayanan data kependudukan sangat diperlukan agar tidak terjadi kesalahan yang tentunya akan berakibat fatal terhadap keakuratan data yang diperlukan. Sistem yang telah terbentuk berfungsi sebagai landasan dalam pelayanan masyarakat pada kantor Dinas Kependudukan dan Pencatatan Sipil Kota Magelang sebagai pelaksanaan pelayanan.

Pemerintah Kota atau Kabupaten memiliki tugas untuk memberi pelayanan administrasi kependudukan kepada masyarakat. Mulai dari desa atau kelurahan yang menjadi tempat awal registrasi data penduduk sampai setiap masyarakat terdaftar secara administrasi sebagai warga Negara Indonesia sesuai Undang - Undang Nomor 23 Tahun 2006 tentang Administrasi Kependudukan. Namun masih terdapat beberapa kelemahan sistem kependudukan pada proses pelaksanaannya.
Pemerintah mengharapkan tata kelola pemerintah yang baik dengan mampu memberi pelayanan yang terbaik kepada masyarakat dengan cara menciptakan teknologi informasi dibidang sistem informasi manajemen penerimaan pengelolaan permohonan administrasi kependudukan. Sistem informasi manajemen penerimaan pengelolaan permohonan administrasi kependudukan (SIMP3AK). Pelayanan menggunakan SIMP3AK diluncurkan pada awal Maret 2018. SIMP3AK sendiri merupakan aplikasi terpadu yang digunakan sebagai alat bantu dalam meningkatkan efektivitas implemetasi dari bermacam regulasi bidang pengelolaan kependudukan dan catatan sipil yang berdasarkan pada asas efisiensi, ekonomis, efektif, transparan, akuntabel dan auditable (www.djpc.kemendagri.gp.id).

SIMP3AK diterapkan untuk memajukan sistem pelayanan administrasi kependudukan khususnya untuk semua masyarakat Kota Magelang untuk mengatasi berbagi permasalahan yang sering dikeluhkan masyarakat. Pada sistem SIMP3AK didalamnya termasuk pengembangan pelayanan kepada masyarakat dan penyelenggaraan Kartu Tanda Penduduk elektronik. Pembuatan KTP-el diharapkan dapat lebih cepat, namun terdapat kendala yang menjadikan sistem SIMP3AK tidak mampu berjalan secara efektif dan efisien seperti yang diharapkan mengakibatkan keterlambatan proses pembuatan Kartu Keluarga, Kartu Tanda Penduduk beserta administrasi kependudukan lainnya.

Berbagai kegiatan sekarang ini disokong dengan berbagai teknologi yang modern. Penggunaan teknologi diharapkan mampu memberikan dampak positif dalam penerapan Sistem informasi manajemen penerimaan pengelolaan permohonan administrasi kependudukan (SIMP3AK), dari individu serta organisasi mampu melakukan aktivitas yang ada secara lebih efektif dan efisien. Berdasarkan latar belakang tersebut, maka penulis tertarik melaksanakan penelitian lebih mendalam terkait permasalahan tersebut dengan judul "Efektivitas Sistem Informasi Manajemen enerimaan Pengelolaan Permohonan Administrasi Kependudukan (SIMP3AK) Pada Dinas Pencatatan Sipil Kota Magelang. 


\section{TINJAUAN PUSTAKA Efektivitas}

Setiap operasi harus menentukan unsur yang harus ada untuk mencapai target atau tujuan dari organisasi disebut dengan efektivitas. Tercapainya target atau sasaran yang telah dirumuskan sebelumnya dapat dikatakan efektif. Efektivitas yaitu tercapainya target yang telah ditentukan sebelumnya. Efektivitas program mampu dikerjakan dengan kempuan operasional untuk melaksanakan program-program kerja yang sesuai dengan terget yang sudah ditentukan sebelumnya.

Pengertian efektivitas menurut (Setiawan, A., Hermini, R., \& Manar, 2013) merupakan keahlian untuk memutuskan tujuan yang akurat dalam rangka mewujudkan tujuan yang telah ditentukan. Dari pengertian tersebut dapat ditarik kesimpulan bahwa pencapaian target sasaran merupakan ukuran yang digunakan untuk memutuskan efektivitas suatu organisasi. Eektivitas penyelesaian kegiatan tepat pada waktu yang telah ditetapkan artinya apakah suatu realisasi tugas dinilai baik atau tidak bergantung bagaimana tugas tersebut dikerjakan atau tidak, terutama memenuhi pertanyaan bagaimana cara menjalankan tugas dan berapa biaya yang dikorbankan.

(Gibson, J. L., Ivancevich, J. M., \& James, 1996) mengatakan bahwa ukuran efektivitas suatu organisasi sebagai berikut

a. Produksi merupakan kemampuan untuk menciptakan produk baik jumlah maupun mutu sesuai dengan permintaan

b. Efisiensi adalah pemaksimalan sumber daya dalam kegiatan produksi

c. Kepuasan adalah tingkat ukur ketika kebutuhan masyarakat dapt terpenuhi oleh organisasi

d. Keunggulan adalah ketika terjadi suatu perubahan baik dari dalam maupun luar, suatu organisasi dapat dengan cepat untuk mengatasinya.

e. Pengembangan seiring dengan permintaan masyarakat yang meningkat organisasi harus dapat memebuhi kebutuhan dengan cara mengembangkan kemampuan organisasi.

\section{Sistem dan Informasi}

Sistem merupakan gabungan dari suatu elemen yang saling berhubungan satu dengan lainnya serta berperan dalam meringankan kegiatan guna mencapai tujuan. Komponen dari sistem saling berhubungan bekerja sama membentuk satuan unit. Sub sistem terbentuk dari beberapa komponen sistem atau elemen sistem. Sub sistem memiliki perannya masing masing yang berbeda namun signifikan dalam proses operasi sistem secara menyeluruh.

Suatu sistem memiliki target yang hendak dicapai. Target yang telah ditentukan akan berpengaruh kepada yang diperlukan oleh sistem dan apa yang diproduksi oleh sistem itu sendiri. Informasi adalah data yang diolah kemudian hasilnya dapat dimanfaatkan menjadi dasar atau pedoman dalam pengambilan keputusan. Pada dasarnya sistem pengolahan mengubah data menjadi informasi yang berguna untuk pemakainya.

Kualitas suatu iformasi berkaitan dengan suatu keputusan. Penentuan sebuah keputusan sangat dipengaruhi oleh kualitas informasi yang di peroleh. Apabila tidak mengambil suatu keputusan, maka informasi tidak dibutuhkan. Keputusan sendiri terdiri dari beberapa macam, seperti keputusan yang sederhana hinga keputusan komplek dalam jangka panjang. Manfaat utama dari suatu informasi adalah menambah wawasan serta mengurangi hal yang tidak tentu kebenarannya. Informasi yang didapat dalam penentuan keputusan berguan untuk mengurangi pilihan-pilhan yang ada untuk mendapat keputusan yang dirasa tepat.

\section{Efektivitas Sistem Informasi}

Efektivitas sistem informasi adalah pengukuran dari kegiatan memberi jasa, pelayanan, dan produktivitas secara lebih maksimal, kegiatan itu didalamnya termasuk input, process, dan output dari data-data atau kejadian berdasarkan aktivitas yang ada perusahaan. Untuk mendapat keputusan yang berguna dan berarti maka harus terdapat komponen yang terstruktur terdiri dari : sistem kerja, perangkat keras, perangkat lunak, jaringan komunikasi, sumber data, manusia dan sumber daya yang digunakan untuk mengumpulkan, mengelola, menganalisa, menyimpan, dan menyediakan produksi jasa, pelayanan,dan produktivitas yang lebih baik (Lestari, L., Lengkong, F. D., \& Tampi, 2016).

Pengukuran implementasi program tersebut efektif atau tidak dapat dilihat dari tiga dimensi, yaitu

a. Organisasi

Struktur organisasi yang jelas harus dimiliki oleh sebuah organisasi, tenaga pelaksana yang dijalankan oleh sumber daya manusia serta peralatan dan perlengkapan yang 
diimbangi oleh seperangkat hukum yang jelas, sejak awal penetapan design dari komponen atau subsistem, struktur organisasi harus sudah diterapkan yang berguna untuk mendukung segala implementasi dari sistem informasi. Kemampuan aparatur untuk menjalankan segala tugasnya berkaitan dengan sumber daya manusia. Keahlian untuk menjalankan tugasnya secara baik harus dimiliki oleh setiap aparatur pemerintah.

b. Interpretasi

Dalam tahapan implementasi tingkatan pengetahuan aparatur berpengaruh pada interpretasi Interpretasi bergantung terhadap taraf pemahaman apparat pelaksana pada tahapan impelementasi, petunjuk pelaksanaan dan petunjuk teknis apakah dilakukan sesuai dengan prosedur yang berlaku, diantaranya:

1. Ketepatan dengan aturan, maksudnya tiap aturan berlaku yang ada harus dijadikan patokan dalam menjalankan kegiatan.

2. Ketepatan dengan petunjuk pelaksanaan, maksudnya sudah terdapat petunjuk dalam pelaksanaan dari aturan yang dijelaskan secara terperinci, pelaksana hanya perlu mengikuti petunjuk dalam menjalankan program.

3. Ketepatan dengan petunjuk teknis, maksudnya peraturan yang ada dirancang kembali secara terperinci supaya lebih mudah dalam menjalankan program.

c. Penerapan

Penerapan yang maksudnya ketentuanketentuan dilaksanakan sesusai dengan petunjuk pelaksanaan dan petunjuk teknis. Hal ini bisa terlihat dari :

1. Dalam menjalankan program kerja harus terdapat prosedur kerja yang jelas sehingga dalam kegiatan operasinya tidak terjadi kesalahan.

\section{III.}

\section{METODE PENELITIAN}

Penelitian ini adalah penelitian kualitatif. Berdasarkan hasil wawancara peneliti mengumpulkan data primer adalah data empiris
2. Agar sasaran dari program dapat terlaksana dengan baik maka program kerja harus deprogram dan direncanakan sebaik mungkin.

3. Terdapat batasan waktu dalam penyelesaian program kerja untuk memudahkan dalam meninjau kinerja yang telah dilakukan.

\section{Sistem Informasi Manajemen Penerimaan Pengelolaan Permohonan Administrasi Kependudukan}

Sistem administrasi negara didalamnya terdapat Sistem informasi manajemen penerimaan pengelolaan permohonan administrasi kependudukan yang berperan dalam pemerintahan dan pembangunan administrasi kependudukan. Berdasarkan (Undang-Undang Republik Indonesia Nomor 23 Tahun 2006 Tentang Administrasi Kependudukan, 2006), yang dimaksud dengan administrasi kependudukan merupakan segala aktivitas pengorganisasian dan publikasi pada penerbitan dokumen serta dokumen kependudukan melewati registrasi penduduk, pencatatan sipil, pengolahan informasi administrasi kependudukan dan menggunakan hasilnya untuk melayani kebutuhan masyarakat dan pembangunan pada sector lainnya.

Pemerintahan terkecil seperti desa sampai skala nasional penting untuk melaksanakan administrasi kependudukan. Tata kelola bidang administrasi kependudukan berperan sebagai tambahan informasi tentang kependudukan untuk membuat peraturan dalam proses pelayanan publik dan kepentingan masyarakat untuk dapat mengetahui informasi hasil administrasi kependudukan tersebut. Penyelenggaraan pemerintah dan pembangunan sangat dipengaruhi oleh informasi kependudukan karena data dari administrasi kependudukan adalah aset negara yang digunakan sebagai acuan dalam perencanaan proses pembanguan. Agar mampu menghasilkan manfaat yang baik dalam proses perbaikan pemerintah dan pembangunan, administrasi kependudukan perlu dikelola dengan sebaik-baiknya.

yang didapat langsung dari narasumber. Penelitian ini menggali perspektif informan tentang seberapa efektif penggunaan Sistem Informasi Manajemen Penerimaan Pengelolaan Permohonan Administrasi 
Kependudukan (SIMP3AK) Pada Dinas Pencatatan Sipil Kota Magelang. Dalam penelitian kualitatif, tingkat kecukupan (representasi) informan tidak hanya ditentukan oleh jumlah atau kuantitas

Tabel 1.

Informan Penelitian informan, tetapi juga ditentukan oleh kualitas informan yang memberikan informasi.

\begin{tabular}{|c|c|}
\multicolumn{1}{|c|}{} & $\begin{array}{c}\text { Tabel 1. } \\
\text { Informan Penelitian }\end{array}$ \\
\hline Kode Informan & Jabatan \\
\hline Informan 1 & Kepala Bidang PIAK dan Pemanfaatan Data \\
\hline Informan 2 & KA Seksi Kerja Sama dan Inovasi Pelayanan \\
\hline Informan 3 & $\begin{array}{c}\text { Operator SIMP3AK Dinas Kependudukan Dan } \\
\text { Pencatatan Sipil Kota Magelang }\end{array}$ \\
\hline
\end{tabular}

Informan penelitian tersebut cukup cakap dan layak untuk memberikan informasi yang dibutuhkan dalam penelitian ini karena informan tersebut selain memiliki posisi strategis dalam lembaga yang dipimpinnya juga terlibat dalam perumusan kebijakan yang ada. Informan yang dipilih berdasarkan kriteria bahwa seorang informan adalah individu yang telah lama berinteraksi dan benar-benar paham dengan kegiatan atau aktivitas yang menjadi objek penelitian. Informan bukan hanya tahudan mampu memeberi informasi, namun juga mengerti secara menyeluruh sebagai dampak dari keikutsertaannya yang telah lama bersama

\section{HASIL DAN PEMBAHASAN}

Sistem informasi manajemen adalah informasi yang saling terhubung yang diperlukan oleh yang berkepentingan dalam melaksanakan tugasnya (kepentingan organisasi), terlebih pada tahap pengambilan keputusan dalam mencapai target organisasi. Manajer mendapat informasi yang digunakan untuk merencanakan kegiatan serta mengawasi jalannya kegiatan yang di dapat dari teknik sistem informasi manajemen. Penggunaan komputer sangat membantu jalannya kegiatan seperti lebih cepat, efektif, dan efisien yang meningkatkan kinerja organisasi tersebut. Agar sistem informasi manajemen dapat berjalan dengan efektif dan efisien perlu pengelolaan yang baik.

Pemerintah dalam upaya peningkatan kualitas dan kuantitas pelayanan masyarakat pada bidang administrasi kependudukan memberikan solusi berupa sistem informasi manajemen penerimaan pengelolaan permohonan administrasi kependudukan (SIMP3AK). Penggunaan sistem informasi manajemen penerimaan pengelolaan permohonan administrasi kependudukan (SIMP3AK) lingkungan maupun kegiatan yang bersangkutan.

Penelitian ini menggunakan teknik wawancara yaitu in depth interview dan studi literature untuk mendapatkan data penelitian yang diinginkan. Data pada penelitian ini diperoleh dari hasil wawancara dan juga menggunakan studi literature terhadap dokumen terkait. Peneliti juga melakukan pengamatan atau observasi adalah suatu teknik yang dilakukan dengan cara mengadakan pengamatan secara teliti serta pencatatan secara sistematis. Peneliti melakukan observasi di Dinas Kependudukan dan Pencatatan Sipil Kota Magelang.

pada instansi pemerintahan secara khusus memiliki peran penting untuk dapat menyajikan laporan yang bermutu. Menurut Perarturan Pemerintah Nomor 24 tahun 2005 dalam lampiran II dijelaskan karakteristik kualitatif laporan keuangan yang merupakan persyaratan normative yang diperlukan agar laporan keuangan pemerintah dapat memenuhi kualitas yang dikehendaki yaitu relevan, andal dapat dibandingkan dan dapat dipahami.

Sistem informasi manajemen penerimaan pengelolaan permohonan administrasi kependudukan (SIMP3AK) merupakan aplikasi terpadu yang dipergunakan sebagai alat bantu pemerintah daerah yang digunakan meningkatkan efektivitas implemetasi dari beragam peraturan pada aspek pengelolaan kependudukan dan catatan sipil yang berdasarkan pada asas efisiensi, ekonomis, efektif, transparan, akuntabel dan auditable. Efektivitas sistem informasi manajemen penerimaan pengelolaan permohonan administrasi kependudukan (SIMP3AK) merupakan suatu acuan atas kegiatan produksi jasa, pelayanan, dan produktivitas agar 
mampu lebih maksimal. Kegiatan yang terkandung didalamnya seperti input, process, dan ouput dari kegiatan atau kejadian pendaftaran administrasi kependudukan. Komponen pendukung kegiatan ini terdiri atas sistem kerja, sumber data, sumber daya, perangkat keras, perangkat lunak yang akhirnya data dikelola dan memberikan informasi yang lebih bermanfaat dan berguna untuk pengambilan keputusan.

Sistem Informasi Manajemen Penerimaan Pengelolaan Permohonan Administrasi Kependudukan pada dasarnya sistem informasi manajemen penerimaan pengelolaan permohonan administrasi kependudukan merupakan subsitem dari organisasi Administrasi Negara. Sistem Informasi Manajemen Penerimaan Pengelolaan Permohonan Administrasi Kependudukan memiliki peran yang signifikan pada pemerintahan dan pembangunan pelaksana administrasi kependudukan. Berdasarkan (Undang-Undang Republik Indonesia Nomor 23 Tahun 2006 Tentang Administrasi Kependudukan, 2006). Dari satuan pemerintahan yang terkecil seperti desa, kecamatan hingga pada skala nasional, administrasi kependudukan adalah hal yang sangat penting untuk dijalankan. Pengolahan administrasi kependudukan mempunyai peran penting dalam informasi tentang kependudukan bagi pemerintah dalam membuat peraturan serta peningkatan pelayanan publik dan kepentingan masyarakat untuk dapat mengetahui informasi hasil dari administrasi kependudukan tersebut.

\section{Tujuan dan manfaat SIMP3AK}

Tujuan diselenggarakannya Sistem Informasi Manajemen Penerimaan Pengelolaan Permohonan Administrasi Kependudukan (SIMP3AK) adalah sebagai berikut:

a. Pengembangan mutu dan kapasitas pelayanan pada Dinas Kependudukan dan Pencatatan Sipil Kota Magelang.

b. Pengadaan informasi yang digunakan sebagai acuan dari kegiatan pemerintahan dan pembangunan.

c. Melakukan pertukaran data informasi dari pemohon yang dilakukan secara tersistem pada pelayanan publik.

Secara teknis implementasi SIMP3AK memiliki sasaran agar:

a. Pemberlakuan Nomor Induk Kependudukan (NIK) sebagai database kependudukan dalam rangka meningkatkan tertib administrasi kepdendudukan. b. Pengintegrasian database kependudukan untuk kepentingan lain, seperti pajak dan imigrasi.

c. Sistem dan data SIMP3AK terhubung dengan kelurahan, kecamatan, pencatatan sipil, dll.

d. Standarisasi nasional.

e. Menerbitkan surat kependudukan seprti kartu keluarga, kartu tanda penduduk, akta dengan mencantumkan NIK Nasional sebagai bentuk perlindungan terhadap hak-hak individu warga negara.

Penerapan SIMP3AK online memiliki fungsi diantaranya :

a. Mempermudah administratif kependudukan serta dengan adanya NIK permasalahan KTP dobel dapat diminimalisir.

b. Masyarakat tidak perlu repot-repot mengurus administratif kependudukan karena dapat dilakukan secra online sehingga lebih efektif dan efisien.

c. Menghapus stigma buruk masyarakat yang beranggapan dalam pembuatan KK/KTP itu susah karena harus menunggu dalam waktu yang lama, biaya mahal, dan harus bolakbalik mengurus administratif pendaftaran. Namun sekarang sudah tersistem dengan baik dengan demikian terlaksananya Good Corporate Governance dalam public services pada Dinas Kependudukan, dan Pencatatan Sipil.

d. Menjadikan landasan untuk meningkatkan sistem yang berguna untuk menciptakan efektivitas dan efisensi pada waktu yang akan dating dan dapat digunakan secara menyeluruh disemua provinsi di Indonesia.

Sebagai bahan pertimbangan dan perbaikan peraturan, perencanaan dan kegiatan untuk para pelaku serta pengelola pembangunan pada aspek kualitas, kuantitas dan perpindahan penduduk, serta keperluan pengembangan lainnya maka digunakan perhitungan dan pengerjaan data statistik yang mendasar baik yang berhubungan dengan peristiwa penting (lahir, mati, kawin, cerai dan lain-lain) maupun peristiwa kependudukan (perubahan alamat, pindah datang dan perpanjang KTP)

$\begin{aligned} & \text { Penerapan } \\ & \text { Penerimaan }\end{aligned} \begin{aligned} & \text { Sistem Informasi } \\ & \text { Pengelolaan }\end{aligned} \begin{gathered}\text { Manajemen } \\ \text { Permohonan }\end{gathered}$
Administrasi Kependudukan (SIMP3AK) Pada
Dinas Pencatatan Sipil Kota Magelang
Penerapan dalam kebijakan mengidikasikan bahwa
Penerapan dalam kebijakan mengidikasikan bahwa 
kaidah teknis sudah berlangsung sejalan dengan pedoman. Agar tetap terlaksana dengan baik harus didukung atas terdapatnya metode kerja, rencana kerja, dan jadwal kegiatan disiplin. Program kerja SIMP3AK pada dinas pencatatan sipil kota Magelang bertujuan agar terlaksana pengembangan Data Base secara Online di 3 Kecamatan di Kota Magelang sehingga memperlancar data dan pelayanan dalam bidang kependudukan.

Dalam mencapai tujuan dari program tersebut, kebijaksanaan-kebijaksanaan dilaksanakan dengan berkoordinasi dengan semua unsur pelaksana. Dari hasil wawancara yang dilakukan dalam implemetasi SIMP3AK sudah menunjukan koordinasi yang lancar dan komunikasi yang efektif. Hal ini sejalan dengan wawancara yang dilakukan bersama Bapak Ahmat Sholichin, S.Sos, MPP, Ec.Dev yaitu :

"Menurut saya, implementasi SIMP3AK ini sudah cukup baik. Telah terdapat berbagai sarana dan prasarana yang mendukung implementasi sistem pada DISDUKCAPIL KOTA MAGELANG. Meskipun terkadang tengah kita temui permasalahan keterlambatan penerbitan KTP, namun secara umum implementasinya cukup efektif dan efisien". (Informan 1)

Selanjutnya penulis juga menanyakan hambatan apa saja yang terjadi dalam pelaksanaan sistem SIMP3AK, hasil wawancara dengan Bapak Ahmat Sholichin, S.Sos, MPP, Ec.Dev yaitu :

"Sebelum dilakukan pendekatan pelayanan (pencetakan KTP/KK), sistem SIMP3AK ini memiliki kelemahan pada pendistribusian karena pencetakan blanko tersebut berada di dinas. Tapi masalah ini sudah terselesaikan dengan pendekatan pelayanan. Hambatan lain saya kira mengenai pengawasan, lemahnya pengawasan terhadap pegawai dapat berakibat pada keterlambatan dalam penerbitan $K T P$, hal ini terjadi bila petugas entri data tidak segera mengirimkan data masyarakat. Hambatan selanjutnya yaitu masalah sosialisasi kepada masyarakat, sosialisasi ini penting dilakukan agar masyarakat tahu prosedur pengurusan administrasi kependudukan yang benar seperti apa" (Informan 1) Berdasarkan hasil wawancara tersebut dapat dilihat meski terdapat hambatan-hambatan dalam pelaksanaan SIMP3AK namun dapat diatasi oleh para petugas, salah satu caranya adalah dengan adanya prosedur kerja yang jelas agar dalam pelaksanaanya tidak terjadi tumpang tindih. Secara keseluruhan bahwa pelaksanaan implementasi Sistem Informasi Manajemen Penerimaan Pengelolaan
Permohonan Administrasi Kependudukan (SIMP3AK) Pada Dinas Pencatatan Sipil Kota Magelang sudah berjalan baik, walaupun masih ada sedikit kekurangannya. Khususnya pada administrasi kependudukan pelayanan yang diberikan kepada masyarakat sekiranya semaksimal mungkin.

\section{Interpretasi Sistem Informasi Manajemen Penerimaan Pengelolaan Permohonan Administrasi Kependudukan (SIMP3AK) Pada Dinas Pencatatan Sipil Kota Magelang}

Interpretasi dapat diartikan dengan pemahaman dari aparat pelaksana implemetasi terhadap pelaksanaan kebijakan. Ini dimaksudkan adalah supaya pengelola implemetasi mengerti yang menjadi tugas dan tanggung jawab serta bagaimana melakukan tugas serta tanggung jawab tersebut. Dari hasil wawancara dapat dilihat bahwa semua operator SIMP3AK mulai dari kepala seksi pemerintahan sampai operator SIMP3AK cukup mengerti akan tugas dan tanggung jawabnya.Hasil wawancara untuk interpretasi ini dilakukan dengan Saudara Anggi Himawan selaku operator SIMP3AK, hasil wawancara adalah :

"Ya, demi kelancaran program SIMP3AK ini sebisa mungkin kita melaksanakannya sesuai dengan peraturan yang ada" (Informan 3)

Wawancara juga dilakukan dengan Bapak M. Hufron G., S.Kom, M.Eng selaku KA Seksi Kerja Sama dan Inovasi Pelayanan, hail wawancara mengenai pertanyaan "bagaimana dengan keterampilan dan keahlian petugas pelaksanaan?"

"Kita telah memberikan pelatihan bagi operator SIMP3AK yang ada pada dinas pencatatan sipil Kota Magelang, selain itu untuk menunjang kinerja kami menyiapkan computer beserta jaringan yang memadai" (Informan 2)

Keakuratan Data dari Sistem Informasi Manajemen Penerimaan Pengelolaan Permohonan Administrasi Kependudukan Dinas Pencatatan Sipil Kota Magelang

Beralaskan hasil penelitian tentang keakuratan data dari Sistem Informasi Manajemen Penerimaan Pengelolaan Permohonan Administrasi Kependudukan (SIMP3AK) pada Dinas Pencatatan Sipil Kota Magelang jika dibandingkan dengan sistem manual,dapat dilihat data yang diinput melalui database jauh lebih akurat dari pada data data yang dibuat secara manual. Namun meskipun demikian tentu ada kelemahan dari penerapan Sistem Informasi Manajemen Penerimaan Pengelolaan Permohonan Administrasi Kependudukan (SIMP3AK) adalah sebagai berikut: 
a. Kekeliruan data penduduk

Pada prosedur menginput data KTP-el, petugas akan menanyakan kepada pemohon apakah datanya telah sesuai atau belum dan melanjutkan prosedur penginputan. Tetapi terdapat kendala yang dihadapi seperti jumlah operator yang terbatas menghadapi jumlah pemohon yang terlampau banyak, yang menyebabkan kelelahan operator dan dapat mengakibatkan kekeliruan pada saat penginputan data.

b. Kekeliruan foto dengan dokumen yang terdaftar

Kesalahan ini bisa saja terjadi akibat Human Error seperti petugas salah memasukan dokumen penduduk ketika proses pendaftaran data untuk KTP-el.

c. Kelemahan yang bersifat teknis

Kaitannya pada proses input data yang menggunakan sistem secara online. Kendalanya terjadi ketika mati listrik, dengan demikian otomatis computer mati dan jaringan yang ada sehingga akan mengganggu jalannya kegiatan. Untuk mengatasinya Dinas Kependudukan dan Pencatatan Sipil Kota Magelang menggunakan genset guna mengganti daya listrik ketika padam. Selain itu mungkin ketika adanya pembaruan sistem maka akan sedikit terganggu pada pengoperasiannya.

\section{Implemetasi Sistem Informasi Manajemen Penerimaan Pengelolaan Permohonan Administrasi Kependudukan (SIMP3AK)}

Administrasi kependudukan dapat berjalan dengan lancer dan sesuai yang diharapkan dikarenakan adanya komunikasi yang baik antara implementor dan masyarakat secara langsung. Berdasarkan wawancara penulis kepada Bapak Ahmat Sholichin, S.Sos, MPP, Ec.Dev yaitu :

"Untuk menciptakan komunikasi yang baik dalam melaksanakan proses adminitsrasi kependudukan diadakan komunikasi yang rutin dan juga intens terkait dengan proses pelaksanaan adminitrasi kependudukan tersebut”. (Informan 1)

Implementasi pelaksanaan Sistem Informasi Manajemen Penerimaan Pengelolaan Permohonan Administrasi Kependudukan (SIMP3AK) dapat diukur dengan efektif atau tidaknya pelaksanaan yang telah dilaksanakan, seperti hasil wawancara dengan Bapak M. Hufron G., S.Kom, M.Eng yaitu:

"Selama ini komunikasi yang dijalin kepada masyarakat sudah cukup baik dan adanya peningkatan dari pemahaman masyarakat mengenai sosialisasi yang kita sampaikan berkaitan dengan administrasi kependudukan yang ada di Kota Magelang. (Informan 2)

Implementasi program SIMP3AK, sumber daya sangat memiliki peran penting, dalam hal ini sumber daya dapat diartikan dalam dua hal yakni sumber daya manusia yang menjadi implementor kebijakan. Pada hal ini yang berperan dalam sumber daya manusia adalah seluruh operator SIMP3AK yang ada di Kota Magelang yang terlibat dalam hal kepengurusan administrasi kependudukan. Hasil wawancara peneliti dengan Bapak M. Hufron G., S.Kom, M.Eng yaitu

"Semua operator SIMP3AK sudah dapat menjalankan kewajiban dan kompetensi secara baik serta memiliki kemampuan dalam melaksanakan Sistem Informasi Manajemen Penerimaan Pengelolaan Permohonan Administrasi Kependudukan (SIMP3AK)”. (Informan 2)

Pelaksanaan Sistem Informasi Manajemen Penerimaan Pengelolaan Permohonan Administrasi Kependudukan (SIMP3AK) pada Dinas Kependudukan dan Pencatatan Sipil Kota Magelang peneliti menemukan bahwa selama ini fasilitas yang ada guna menunjang kinerja sudah cukup baik. Informasi dalam pelayanan kepengurusan administrasi kependudukan sudah diberikan secara baik sejalan dengan yang diinginkan masyarakat, selain itu dalam hal pelaksanaannya diterapkan secara gratis oleh aparatur Dinas Kependudukan dan Pencatatan Sipil Kota Magelang.

\section{KESIMPULAN DAN SARAN}

Kesimpulan

Berlandaskan data yang didapat berkenan dengan efektivitas Sistem Informasi Manajemen Penerimaan Pengelolaan Permohonan Administrasi Kependudukan (SIMP3AK) pada Dinas

Kependudukan dan Pencatatan Sipil Kota Magelang, lalu dapat disimpulkan sebagai berikut :

a. Penerapan Sistem Informasi Manajemen Penerimaan Pengelolaan Permohonan Administrasi Kependudukan (SIMP3AK) pada 
Dinas Kependudukan dan Pencatatan Sipil Keterbatasan

Kota Magelang dinyatakan cukup efektif serta Penelitian telah dijalankan meski terdapat efisien berlandaskan observasi dan tanya jawab keterbatasan dan kekurangan yang bisa berdampak dengan sejumlah narasumber yang cukup dari hasil penelitian yang dijalankan. Keterbatasankompeten serta memadai untuk keterbatasan yang ada dalam penelitian ini adalah menyampaikam informasi yang dibutuhkan sebagai berikut:

pada penelitian ini.

b. Keakuratan data dari Sistem Informasi Manajemen Penerimaan Pengelolaan Permohonan Administrasi Kependudukan (SIMP3AK) dinilai sudah lebih akurat jika dibandingkan dengan sistem manual, karena semua data penduduk sudah didimpan dalam database sehingga pada saat data penduduk dibutuhkan operator tinggal mengakses data yang telah ada. Namun masih ada kelemahan Saran dari program Sistem Informasi Manajemen Penerimaan Pengelolaan Permohonan menimbang keterbatasan dan kekurangan yang Administrasi Kependudukan (SIMP3AK) didapat, dihimbau bagi penelitian yang selanjutnya tersebut yaitu kesalahan data penduduk, untuk dapat membenahi hal-hal berikut ini : kesalahan foto dengan data yang tercantum, kesalahan atau kelemahan yang bersifat teknis.

c. Meski masih terdapat beberapa kekurangan namun secara keseluruhan pelaksanaan implementasi Sistem Informasi Manajemen Penerimaan Pengelolaan Permohonan Administrasi Kependudukan (SIMP3AK) pada Dinas Kependudukan dan Pencatatan Sipil Kota Magelang sudah berjalan dengan baik. Pelayanan administrasi kependudukan yang diberikan kepada masyarakat diharapkan mampu terlaksana efektif dan efisien.

\section{DAFTAR PUSTAKA}

Gibson, J. L., Ivancevich, J. M., \& James, H. D. (1996). Organisasi dan manajemen. Perilaku Struktur, Proses (4th ed.). Erlangga.

Lestari, L., Lengkong, F. D., \& Tampi, G. B. (2016). Implementasi Sistem Informasi Administrasi Kependudukan (Siak) di Dinas Kependudukan dan Pencatatan Sipil Kota Manado. Jurnal Administrasi Publik UNSRAT, 3(400), 74160.

Setiawan, A., Hermini, R., \& Manar, D. G. (2013). Efektifitas Penerapan E-Government Pada Dinas Kependudukan Dan Catatan Sipil Kabupaten Sragen Dalam Program Sistem Informasi Administrasi Kependudukan (SIAK). Journal of a. Jangka waktu observasi yang diberikan hanya 1 bulan observasi yaitu 13 Januari hingga 13 Februari 2020.

b. Sedikitnya jumlah Informan karena keterbatasan tenaga dan waktu peneliti.

c. Keterbatasan data yang di dapat karena dalam penggunaan SIMP3AK masih baru, terbilang dua tahun dari awal penggunaan dan masih dalam proses pengembangan.

a. Menambakan jangka waktu penelitian, dengan jangka waktu yang lebih lama diharapkan hasil yang didapat bisa lebih tepat dan tidak bermakna ganda.

b. Memperbanyak data primer seperti kuesioner yang diajukan kepada pihak dinas untuk mendukung data sekunder yang dipakai.

c. Memperbanyak referensi penelitian yang mampu mendukung topik yang diteliti.
Slamet, D., Retnadi, E., \& Partono, P. (2012). Pengembangan Sistem Informasi Administrasi Kependudukan (Siak) Pada Bagian Pendaftaran Pindah Datang Penduduk Di Dinas Kependudukan Dan Pencatatan Sipil Kabupaten Garut. Jurnal Algoritma, 9(1), 36-45.

Suwarno, Y. (2008). Inovasi di sektor publik. STIA-LAN.

Undang-Undang Republik Indonesia Nomor 23 Tahun 2006 tentang Administrasi Kependudukan, (2006). 